\title{
モザイク動物の肝発癌研究への応用
}

\author{
小川勝洋 旭川医科大学病理学第 1 遇坐

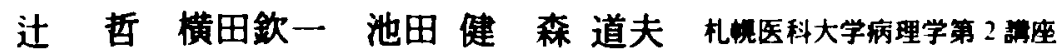

\section{UTILIZATION OF MOSAIC ANIMALS FOR THE STUDIES OF HEPATIC CARCINOGENESIS}

Katsuhiro Ogawa Department of Pathology, Asahikawa Medical College Satoru Tsuji. Kin-ichi Yokota, Tatsuru Ikeda, and Michio Mori Department of Pathology, Supporo Medical College

\begin{abstract}
Properties of hyperplastic hepatic nodules. presumptive preneoplastic lesions of hepatocellular carcinomas, were investigated in mosaic rodents of which livers comprise two genetically-different lineages of cells. In the first experiment, we explored the monoclonality of hyperplastic nodules induced by DEN and phenobarbital in female $\mathrm{C} 3 \mathrm{H} \times \mathrm{spf}$-ash $\mathrm{FI}$ mice of which livers are composed of hepatocytes with and without ornithine carbamyl transferase (OCT) activity. Simultaneous staining for OCT and $\boldsymbol{\gamma}$-glutamyltranspeptidase activities demonstrated that the nodules were composed entirely of one or the other of 2 lineages, representing their monoclonality. The second experiment u as carried out to investigate the phenotypic reversion of early hyperplastic nodules by using transplantation system between analbuminemic rats (NAR) and SD $\times$ NAR FI rats. Hyperplastic nodule cells isolated from NAR were transplanted into the liver of SD $\times$ NAR FI rats of which livers are positive for albumin. In those recipient mosaic rats. hyperplastic nodules were virtually negative for albumin and the surrounding nonhyperplastic nodule cells were positive. It became clear that, although hyperplastic nodules express biochemical markers during administration of promoting stimuli, they revert to become phenotypically normal after removal of the stimuli. (J Toxicol Pathol 1: 61 66, 1988)
\end{abstract}

Key words: Mosaic animal. Hyperplastic hepatic nodule. Hepatocellular carcinoma

\section{序文}

最近，発患過程の研究に，先天的または人工的 に作られた透伝異常娌物を利用する陚みが行われ ている。これらの中には,トランスジェニックマ ウスや、先天代铸異常動物などが含まれるが,我々 は最近、モザイク娌物を肝発禹実駼に用いる研究 を進めている。モザイク動物とは，個体を㩐成す る細胞が, 这伝的に異なる 2 種類以上の練胞から 柃される動物であり，これらのうちある種のも のでは，2種類の細胞を遗伝マーカーを利用して

Accepted for publication : December I, 1987

Mailing address : Katsuhiro Ogawa, Department of Pathology, Asahikawa Medical College, 4-5-3-11, Nishikagura, Asahikawa 078, Japan.
区別することが可能である。我々はこのような 功物を利用し，肝の前密病変と考えられている增 生結節の性曾について，1)その clonalityおよ び，2）プローションと発現形質との関係につ いて検討した。

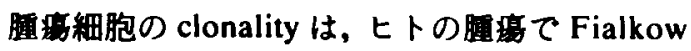
のクループにより，X-linked isozyme marker を もとに生化学的に広く研究されており，ほとんど の腫瘍が monoclonal origin であることが示され

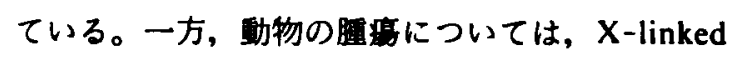
醉素や集合キメラての allo-specific membrane antigen などをマーカーとして，いくつかの随最 monoclonality が証明されている゙。一方, 肝発癌で は, 一個の增生結節が,一個の initiated cell の増 殖によって形成されることを示唆されてきたが, 
すべての結節が monoclonal てあるか否かは議論

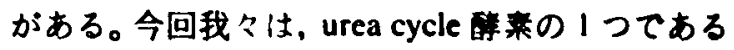
ornithine carbamyl tranferase (OCT) の活性を道 伝的に欠損した sparse fur with abnormal skin and hair (spf-ash) アウマ’と, C3HマウスのFl hybridを用いることにより、粗化学的方法で增 生結節の clonalityを模討した。

一方，初期の剒生結節は，発雷物冝やプロモー ターの投与を中止すると多くのものては、マー カ一が次第に消失し、形箵学的にも正常の肝に類 似して、結節の特政が失かれることが知られてい

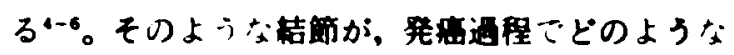
意教をしつのかを到へろためには，従来の生化学 的マーカーはこの目的に汒不十分てある。我々は。 無アルフミンラット(NAR) と, 正常のアルフミ ン産生能を有するラット上の间て肝細胞の肝的移

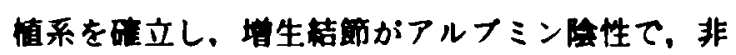
結節部がアルフミン得性になるという人工的なモ ザクラットを作些し、アルフミン㓌性をマー カーとして移植結筬の正命を追跡しだー10。

\section{方 法}

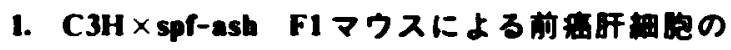 clonality $\sigma$ 模讨}

OCT 施 carbamyl phosphate からリン酸基を荤 して, ornithine: : carbamyl groupを枟移し,

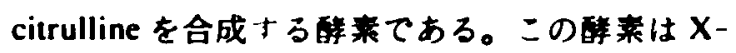
linkedであろため, spf-ash と正学マウスの間に生 まれたFI hybridの;ち, 篗の heterozygoteでは, X染色体の不活化により個々の肝細胞は XPか

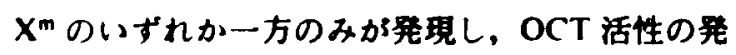
現に阅しては淂性か恰性かのどちらかになる。

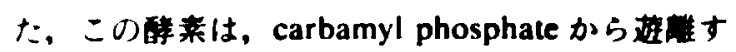
ろリン酸基を利用したフォスフフターゼ反応によ ク，容易に染め出すことが可能てあるい。そこて， spf-ash マウスの雄とC3Hの踓の交眍によるFI の触に, 生後 I週間以内にDENを空内投与し、 3 週目から 0.05\% phenobarbital 食を連続投与し て增生結節を誘発し，3力月から1年にわたる各 時期に屠殺した。肝組織をアセトン固定,パラフィ ン包埋し、水谷の方法により carbamyl phospate を基筫として OTC 活性の染色を行い, 続いて同 じ切片を用いて，增生結節のマーカーである

\section{GGTの染色を行った。}

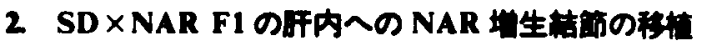

NARの無アルプシン血症は劣性选伝性てある ため, SDXNAR FI ラットてはすへてての肝細胞 がアルプンン産生能を示す。そこてNARを donor とし, SDXNAR F1を recipientとして, 分 略した增生結節細胞を経門脈的に肝内に移植し た。このような物では,アルプシンの有無によっ て, donor 由来の增生結節が娭出てきる。donor の NARにはSolt-Farber 法12により增生結節を誘 発し，6周目にコラゲナーゼを遮流して肝細胞を 熦した。 recipient の SDXNAR F1には，移植 の1迥间前から0.02\% 2-AAF 食を2迥間投与し た。2-AAF 投与開始 1 迥目に2/3 部分肝切除を 行ったのち、渴間膜䑶脈から $2 \times 10^{\circ}$ 個の分離細胞 を注入した。 recipient を移植後 2 迵，8週，9カ月 目に居段し，肝をPLP要流固定・バラフィン包埋

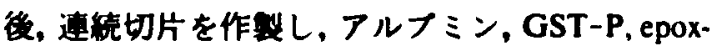
ide hydrolase (EH), GGT の免度染色を行った。

\section{鼓}

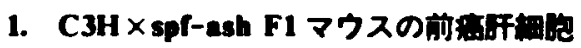

正常のC3H マウスの解組ては，OCT 活性は 肝小莱の周辺部て強く，中心部に弱い傾向が見ら れたが、すべての甿胞に淂性てあった(図 1a)。一 方, spf-ash マウスでは，すへての肝細胞が OCT 㓌性て、阳性細胞は全く認められなかった。これ に対して C3HXspf-ash F1 マウスでは，隭性細胞 と陰性細胞が混在してモザイクを示していた（図 Ib)。

DEN-phenobarbital 処园群ては，看々の大きさ のGGT 泩策が見られ，小さなものは 1 個の細 胞からなり，大きなものては数百個の細胞から なっていた。OCTとGGT の二重染色ではGGT は細胞膜に赤色に染まり, OCTは細胞賁に袹色に 染まろため、両者は明睰に区別することが出来た。 GGT 淂性の areaは，大きさに防係なく，検索した すへての結節で, OCTは陶性か隍性かのいずれか てあり，晹性細胞と陰性細胞の両方からなるモザ イク状の結節は全く認められなかった（図 2a，b)。 また, OCT 晹性結節と隍性結節の剖合はほほ $1: 1$

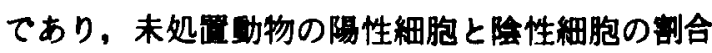




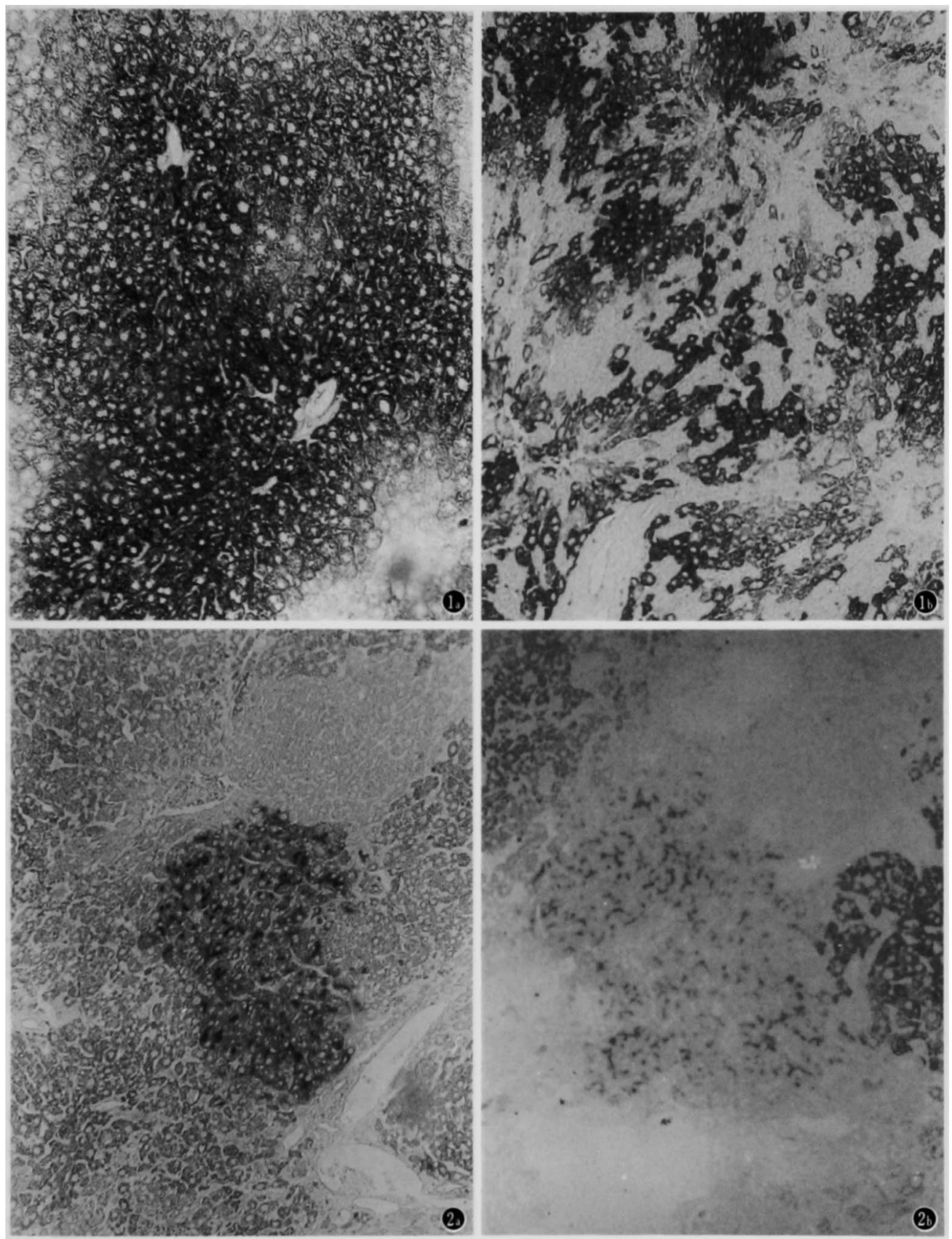

図 I. 正常 C3H マウス (a) と正常 C3H Xspf-ash FI 鹳マウス (b) の肝 OCT 活性架色。

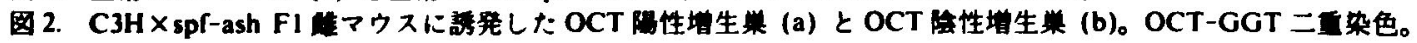

と一致した。

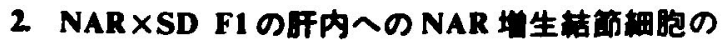 移等}

正常の SD, F344 ラットに誘発した增生結節や 肝者では，種々の程度にアルフミンが性て，発
禹過程で肝細胞のアルフミン産生能の消失が起こ らないことが確認された。したがって，上記の移 植実験で recipientにみられたアルブミン陰性の 結節は donorに由来したものと判定された。

移植後 2 週目では recipient の肝内に多数の結 節がみられ(90個 $\left./ \mathrm{cm}^{2}\right)$,アルブミン染色はすへて 

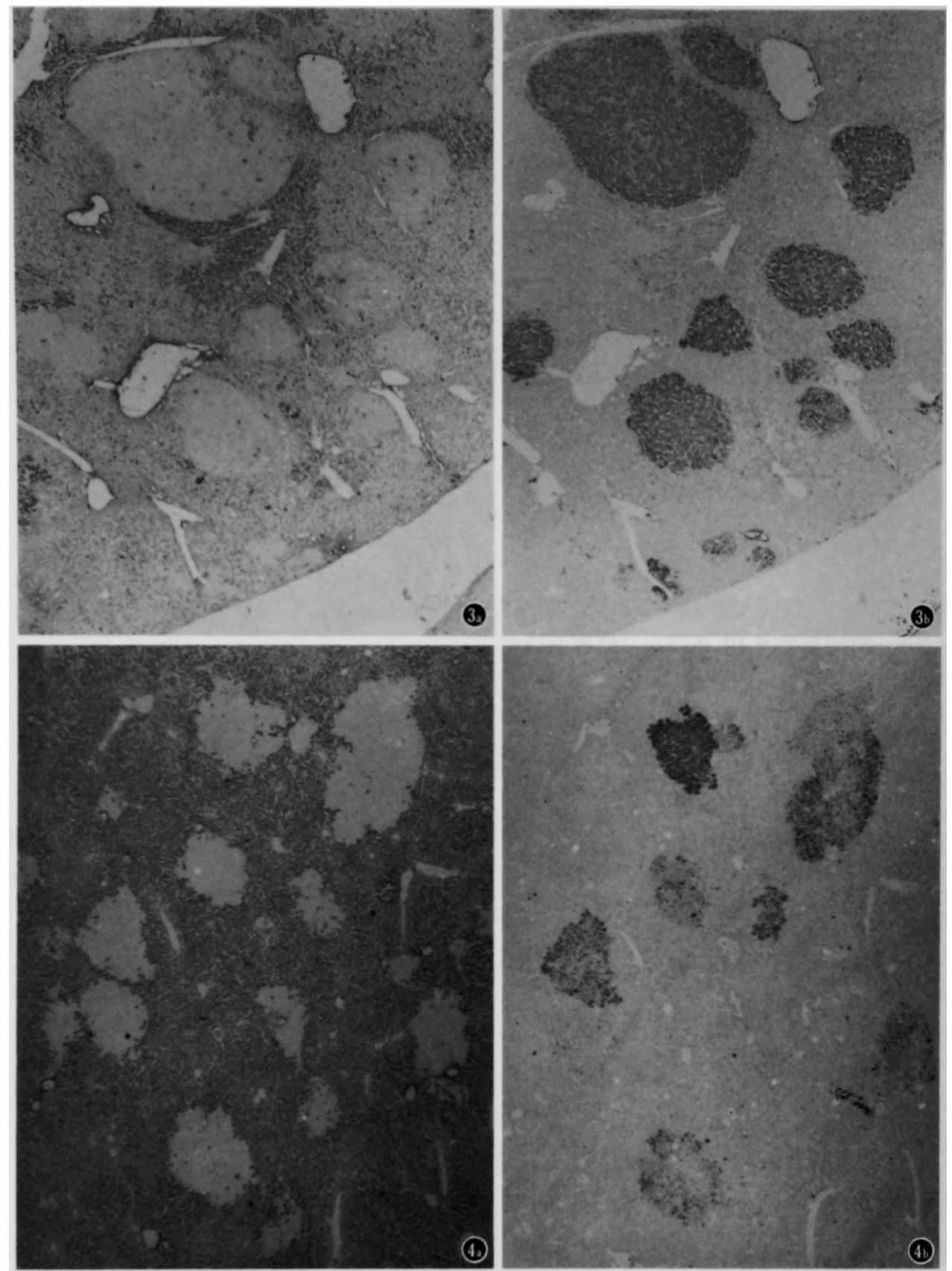

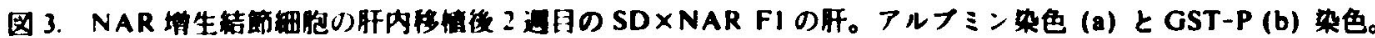

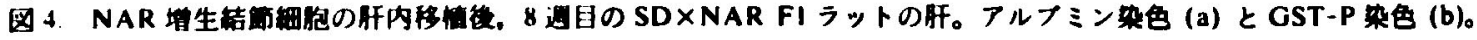

が隆性て， donor origin であった(図 3a)。連続切 片在用いて生化学マーカーについて模索したとこ ろ，アルフミン陰性結節のうち 98\%か GST-P陽 性 (図 3b)，94\% 力; EH 䧉性, 60\% 力: GGT 陽性て, 3つのマーカーが同時に発現していたものは 59\% てあった。移植後 8 遇目では, アルフミン陰性結
節の単位面䅡当たりの数は 2 週目とほとんど同じ でったが (図 4a)，GST-P 陽性のものは 43\% (図 4b)、EH 陽性のものは 43\%，GGT 陽性のものは 22\%で，3つが同時に陽性のものは $18 \%$ に過ぎな かった。9カ月後ては、アルブミン㓌性結節は增大

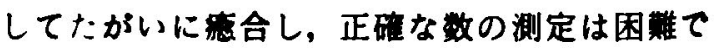


あったが、マーカーの発現は 8 週目とほほ同様て あった。

アルフミン狯性結節の形態は，2週目ては周用 压排性て塩基好性を示したが,8週,9カ月目で， 大部分は正常肝とほほ同じ組䄉像を示し，細胞質 が好酸性ないしは空胞状て，周囲圧排性を示すも のは少数てあった。

\section{戠}

\section{1. 增生喆简の clonality}

肝增生結節が monoclonal origin てあることは 以前から示唆されていた。例えば，GST-Pなどの 增生結節のマーカーを持つ湅胞が 1 個の単位で見

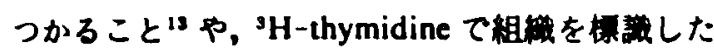

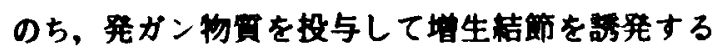
と，增生結節の標臷が次第に希规されるこどが 報告されている。また生化学的には，X-linkedの 啸秦マーカーを持つモザイク较物の結節ては，大 部分がアイソザイムの一方のみを発現することが

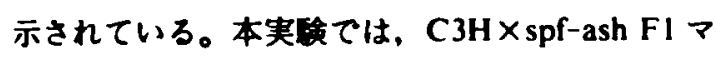
ウスを用いてDENによる initiationと。 phenobarbitalによる promotion の組み合わせに より誘吐した增生結節の clonality を組織化学的 に检討した。もし、增生結節が苓数の細胞を起源 として発生するとすれば,このようなモザイク組

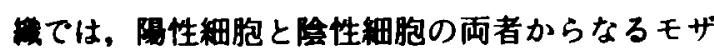
イク結節が存在するはずである。しかし，そのよ うな結節が全く覞察されなかったことは，各增生 結節が monoclonal 起源てあることを示してい る。

従来の生化学的方法による clonality の模案て

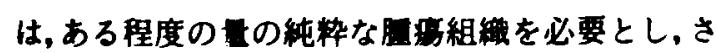

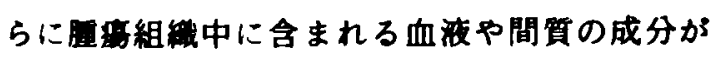
alloenzyme p alloantigen の解析の障害になる。 我々の示した組䄉化学的方法では結節のマーカー と息伝マーカーの同時染色が可能であり, 顆微鏡 レヘルの䵇小な病変についても, clonality の满索 が可能であった。

\section{2. 增生跿第の表現形页の正常化}

SD XNAR F1 に移植した細胞は，NAR の結節 細胞と周囲の正常肝細胞との混合であるが, 移植 後 2 週目では，大部分の結節は生化学的マーカー
を示していた。すなわち、この系で recipientに生 着したものは, donor の結節細胞のみて, NAR 由 来の正常細胞は生著し得なかったことを示してい ろ。8 週目になると半数以上の recipient の結節は いずれの生化学マーカーも示さず, 形隹学的にも ほとんど正常であった。このことは，いったん生 着した結節細胞は，プローションの影整のある 間は生化学マーカーを発現するが，その刺擞がな くなると、形筫が正常化することを示している。す なわち、結節は一見退縮したかにみえるが, 正常 に近い形に形䨘変化したことがわかる。これまて 同様の現象は, 生化学的マーカーを用いて調べら れてきたか，今回の覞察のように完全にマーカー を失うものがあると、それらはとらえることの出 来ない現象でった。このようにモザイク助物を 利用することにより、結節湅胞の in vivo ての形質 変化を正礁に追跡することが可能である。

本実簋に用いた結節細胞の肝内移植は, Laishes ら15により報告されたモデルを改良したものであ る。彼らが用いた同系娌物同士の移植では，マー カーは従来の生化学マーカーを用いるため, 結節 の運命を追跡する意味では通常の発盘実硢と変わ クがない。Hunt ら ${ }^{16}$ は、Wistar/Furthまたは F344 をdonor とし, Wistar/Furth XF344 Fl を recipient として, allo-specific membrane antigen を这伝 マーカーに用い，移植細胞を証明した。我々のモ デルはアルプミンを遭伝マーカーとするため, Hunt ら ${ }^{10}$ が凍結切片での蛍光抗体法を用いるの に対して，PLP 逼流固定・パラフィン包埋材料を 用いることが出来, 広い筑囲の㭘索が可能で, し かも従来の生化学的マーカーとの对比が容易であ ろなど,多くの利点がある。

近年, 疾患モデルとして, 種々の遗伝異常をも つ轩物の系か確立されている。これらの物物は，そ れぞれの特性を生かすことにより, 発看研究にも 有奻に利用することが出来る。本小論では, NAR またはspf マウスと正常とのモザイク動物を肝化 学発ガン過程の研究に応用した著者らの最近の成 結を紹介した。

\section{女 献}

1. Fialkow, PJ: Clonal ; origin of human tumors. Biochim Biophys Acta 458 : 283-321, 1976. 
2. lannaccone. PM. Weinberg. WC, and Deamant, FFD: On the clonal origin of tumors : a review of experimental models. Int J Cancer 39: 778-784. 1987.

3. DeMars, R, LeVan. SL. Trend, BL, and Russell, LB : Abnormal ornithine carbamoyltransferase in mice having the sparse-fur mutation. Proc Natl Acad Sci USA 73 : 1693-1697, 1976.

4 Enomoto, $K$ and Farber, E : Kineties of phenotypic maturation of remodeling of hyperplastic nodules during liver carcinogenesiv Cancer Res 42 : 2330-2335, 1982.

5 Ogawa. K. Solt. D. and Farber, E: Phenotypic diversity as an early property of putative preneoplastic hepatocyte populations in liver carcinogenesis. Cancer Res 40 : 725-733, 1980.

6. Tatematsu. M. Nagamine, $Y$, and Farber, $E$ : Redifferentiation as a basis for remodeling of carcinogen-induced hepatocyte nodules to normul appearing liver. Cancer Res 13 : S049-5048. 1983

7. Nagase. S. Shimamune. $K$. and Shumiya, $S$ : Albumin-deficient rat mutant. Science 205 : 590-591, 1979.

8. Ogan a. K, Yokota. K. Tsuji, S. Takasaka, H, Mori, $M$, and Nagive. $S$ : Transfer of albumin-negative hyperplastic nodule cell, to the albumin-positive livers of analbuminemic $\times S D$ hybrid rats. Proc Am Assoc Cancer Res 28 : 165, 1987.

9. Yokota, K, Ogawa, K. Mori, M, and Nagase, S: Transplantation of putative preneoplastic hepatocytes of analbuminemic rats in the livers of
Sprague-Dawley $X$ analbuminemic hybrid rats. Jpn J Cancer Res 78 : 109-112, 1987.

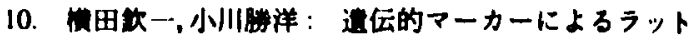

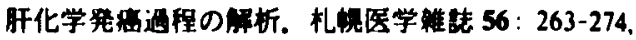
1987.

11. Williams, ED. Wareham, KA, and Howell, S: Direct evidence for single cell origin of mouse liver tumors. Br J Cancer 47: 723-726. 1983.

12. Solt, D and Farber, E: New principle for the analysis of chemical carcinogenesis. Nature 236 : 70I-703. 1976.

13. Moore. MA. Nakamura, T, and Ito, N : Immunohistochemically demonstrated glucose-6-phosphatate dehydrogenase, $\boldsymbol{\gamma}$-glutamyl transpeptidase. ornithine decarboxylase and glutathione S-transferase enzymes: absence of direct correlation with cell proliferation in rat liver putative preneoplastic lesions. Carcinogenesis 7: 1419-1424, 1986.

14. Scherer, E and Hoffmann, $M$ : Probable clonal genesis of celfular islands induced in rat liver by diethylnitrosaminc. Eur J Cancer 7: 369-371, 1971.

15. Laishes, BA and Farber, E: Transfer of viable putative preneoplastic hepatocytes to the livers of syngeneic host rats. JNCl 61 : 507-512, 1978.

16. Hunt, JM, Buckley, MT, Onnink. PA, Rolfe. PB, and Laishes, BA : Liver cell membrane alloantigens as cellular marker in genotypic mosaic rat livers undergoing chemically induced hepatocarcinogenesis. Cancer Res 42 : 227-236, 1982. 